JURNAL PANGAN DAN GIZI Vol (No): 45-59, April 2020

ISSN (Online) : 2656-0291

Tersedia online di http://jurnal.unimus.ac.id/index.php/JPDG

\title{
SIFAT FISIK, SIFAT ORGANOLEPTIK DAN AKTIVITAS ANTIOKSIDAN SUSU BUBUK KEDELAI HITAM BERDASARKAN KONSENTRASI TWEEN 80
}

\section{Physical Properties, Organoleptic Properties and Antioxidant Activity of Black Soybean Milk Powder Based on Tween 80 Concentration}

\author{
Riska Ciptasari, Nurrahman \\ Program Studi S1 Teknologi Pangan \\ Universitas Muhammadiyah Semarang \\ Email : riskaciptasari@gmail.com
}

\begin{abstract}
Soy milk is one alternative to cow's milk for lactusa intolerance patients. The utilization of black soy less is attention and not as popular as yellow soybean because of the color that is less interesting. Another alternative in the processing of milk is the manufacture of milk powder. Processing of instant soy milk powder using foam-mat drying method required addition of filler material ie maltodextrin and Tween 80. With the addition of proper Tween 80 concentration expected to produce more stable milk powder. The general purpose of this research is to know the effect of Tween 80 concentration variation on physical properties, organoleptic properties and antioxidant activity of black soybean milk powder. Experimental method of experimental type using Completely Randomized Design (RAL) monofactor with Factor addition of Tween 80 concentration $(0,0,25,0,5,0,75$ and 1 percent). The product analyzed physical properties (water absorption, moisture content, solubility and settling rate), organoleptic properties and antioxidant activity. The best result of antioxidant activity was 33,70\% RSA at concentration $0,25 \%$, water absorption $2,77 \mathrm{ml} / \mathrm{g}$ at concentration $0,25 \%$, water content, $8,98 \%$ at concentration $0,25 \%$, solubility $84,435 \%$ at a concentration of $0.75 \%$ and a precipitation rate of $10 \mathrm{~s}$ at a concentration of $0.25 \%$. While the best organoleptic test is at concentration $0.25 \%$. The conclusions of the research on black soybean milk powder with the addition of Tween 80 concentration showed a real difference for each test conducted where black soybean milk powder with the addition of Tween $800.25 \%$ concentration was the best treatment.
\end{abstract}

Keywords: black soybeans, milk powder, Tween 80, antioxidants

\section{PENDAHULUAN}

Susu merupakan salah satu minuman sumber gizi yang penting bagi tubuh. Susu sapi mengandung laktosa yang tidak cocok dikonsumsi bagi penderita lactose intolerance. Susu kedelai merupakan salah satu alternatif susu nabati yang murah dengan sumber protein tinggi. 
Menurut Jiang et al., (2013) susu kedelai memiliki kombinasi nutrisi yang seimbang, yang hampir mirip dengan susu sapi tetapi bebas gluten, kolesterol dan laktosa. Susu cair merupakan bahan pangan yang perishable (mudah rusak) karena mempunyai kadar air tinggi sekitar 87 - 90 persen. Oleh karena itu, perlu dilakukan pengolahan untuk mempertahankan kualitasnya salah satunya adalah pembuatan susu bubuk.

Kedelai yang lebih banyak digunakan dalam produk pangan adalah kedelai kuning misalnya diolah menjadi tahu, tempe, kecap dan susu kedelai. Pemanfaatan kedelai hitam pada umumnya hanya untuk kecap, tempe dan tauco. Pemanfaatan kedelai hitam kurang mendapat perhatian dan tidak sepopuler kedelai kuning dikarenakan warnanya yang kurang menarik (Noer et al., 2009).

Sifat emulsi pada susu kedelai cenderung kurang stabil sehingga susu kedelai kurang diminati masyarakat karena mudah mengendap (Kurniasari et al.,
2010). Salah satu cara untuk mengatasi pengendapan tersebut dengan cara penambahan bahan pengisi. Menurut Purbasari (2016) pengolahan bubuk susu kedelai instan menggunakan metode foammat drying diperlukan penambahan bahan pengisi Tween 80 .

Dengan penambahan konsentrasi Tween 80 yang tepat diharapkan dapat menghasilkan susu bubuk yang lebih stabil, yaitu ketika susu bubuk dicairkan akan tercampur antara padatan dan cairan dari susu bubuk kedelai hitam serta ada pengaruh penambahan konsentrasi Tween 80 terhadap aktivitas antioksidan, sifat fisik (daya serap air, kadar air, tingkat kelarutan dan laju pengendapan) dan sifat organoleptik (warna, aroma, rasa dan tekstur) susu bubuk kedelai hitam. Tujuan dari penelitian ini adalah untuk mengetahui pengaruh variasi konsentrasi Tween 80 terhadap aktivitas antioksidan, sifat fisik dan sifat organoleptik susu bubuk kedelai hitam.

\section{BAHAN DAN METODE}


Bahan

Bahan yang digunakan adalah

kedelai hitam varietas Detam-1 yang diperoleh dari Balai Penelitian Kacangkacangan dan Umbi-umbian Malang. Bahan pengemulsi dan pengisi dekstrin dan Tween 80 diperoleh dari toko Kimia Raya Semarang. Bahan-bahan kimia yang digunakan dalam analisis komponen fisik dan antioksidan adalah Larutan DPPH dan aquades.

\section{Metode}

Pembuatan Susu Bubuk Kedelai Hitam (Modifikasi dari Pertiwi, 2013 dan Sari et al., 2016)

Kedelai hitam dicuci, kemudian direndam selama 6-7 jam. Setelah itu dilakukan proses pengupasan kulit kedelai hitam. Dilakukan blanching dengan suhu $90{ }^{\circ} \mathrm{C}$ dengan waktu 5 menit Selanjutnya proses penggilingan dengan blender dan ditambahkan air sedikit demi sedikit. Penambahan air secara keseluruhan adalah 1 : 8 dari berat kering bahan. Setelah itu, susu disaring dan direbus kemudian ditambahkan $7,5 \%$ gula dari berat kering bahan untuk menghasilkan sari kedelai hitam. Pembuatan susu bubuk kedelai hitam dilakukan dengan memvariasi konsentrasi bahan pembusa (Tween $80 ; 0,0,25,0,5$, 0,75 dan 1 persen) dan bahan pengisi (dekstrin 5\%) dengan suhu pengeringan $70^{\circ} \mathrm{C}$ selama 6-8 jam untuk mengetahui karakteristik susu kedelai bubuk yang dihasilkan.

\section{Analisa Aktivitas Antioksidan dengan metode DPPH (Tamrin, 2012)}

Sampel ditimbang sebanyak 0,5 g lalu di ekstrak dengan $5 \mathrm{ml}$ methanol selama 2 jam. Ekstrak diambil $0,1 \mathrm{ml}$ dan direaksikan dengan 3,9 ml larutan DPPH 6 x $10^{-5} \mathrm{~mol} / \mathrm{L}$ (2,9 mg DPPH dalam $100 \mathrm{ml}$ methanol) selama 30 menit dengan absorbansi $\mathrm{t}=0$ dan panjang gelombang $\lambda$ 517 nm. Methanol digunakan sebagai blanko. Hasil \% RSA (Radical Scavenging Activity) dinyatakan dengan persamaan sebagai berikut

$$
\begin{aligned}
& \% \quad \mathrm{RSA} \quad=\quad[1- \\
& \left.\frac{(\text { absorbansi sampel })}{\text { absorbansi kontrol }} \times 100 \%\right]
\end{aligned}
$$


Keterangan :

Abs kontrol = absorbansi $\mathrm{DPPH}$ pada waktu ke-0

Abs sampel = absorbansi $\mathrm{DPPH}$

pada t menit

Daya Serap Air (Traina dan Breene, 1994)

Sampel seberat $1 \mathrm{~g}$ dicampur dengan $10 \mathrm{~mL}$ air suling didalam test tube, dikocok selama 1 menit kemudian didiamkan selama 30 menit pada suhu ruang. Selanjutnya test tube disentrifugasi dengan kecepatan 2000 RPM selama 25 menit. Jumlah air yang tertahan pada sampel setelah penirisan test tube disebut kapasitas daya serap air. Kapasitas daya serap air dinyatakan dengan persamaan sebagai berikut :

Daya serap air $(\mathrm{ml} / \mathrm{g})=$
Masukkan 2 g sampel kedalam botol timbang yang sudah di oven selama 1 jam kemudian timbang. Panaskan botol timbang yang berisi sampel dalam keadaan botol terbuka dengan meletakkan tutup botol disamping botol didalam oven pada suhu $105^{\circ} \mathrm{C}$ selama 5 jam (5 jam setelah suhu oven $105^{\circ} \mathrm{C}$ ). Tutup botol timbang ketika masih didalam oven kemudian segera pindahkan ke dalam desikator dan dinginkan selama 15 menit lalu timbang. Selanjutnya dipanaskan kembali selama 30 menit, didinginkan kembali didalam desikator dan ditimbang. Perlakuan ini diulangi sampai tercapai berat konstan. Pengurangan berat merupakan banyaknya air yang diuapkan dari bahan, dengan perhitungan :

Kadar air

(\%) =

berat sampel

\section{Kelarutan (Less, 1971)}

Kelarutan susu bubuk kedelai hitam

Kadar Air Metode Gravimetri

(Sudarmadji et al., 1984) dilakukan dengan cara $13 \mathrm{~g}$ sampel dicampur dengan $100 \mathrm{~mL}$ air aquades selama 3 menit selanjutnya dibiarkan 
selama 15 menit sebelum disentrifugasi dengan kecepatan 1000 RPM selama 5 menit. Jumlah total zat padat didalam supernatant ditentukan dengan cara pengeringan oven pada suhu $100{ }^{\circ} \mathrm{C}$ hingga mencapai berat konstan. Kemudian didinginkan dalam desikator hingga mencapai suhu ruang kemudian dilakukan penimbangan. Persen kelarutan dinyatakan dengan rumus sebgai berikut :

$\% \quad$ Kelarutan =

$\frac{\text { berat endapan kering }}{\text { volume supernatant }} \times 100 \%$

Uji Laju Endapan (Anjani et al., 2011)

Uji dilakukan pada masing masing perlakuan yang ditambahkan dengan air $200 \mathrm{ml}$ dengan bobot susu bubuk 20 gram kemudian diaduk hingga merata lalu dihitung waktu terdispersi dan mulai terbentuknya endapan.

\section{Uji Organoleptik Uji Hedonik dan Mutu}

Hedonik (Modifikasi Setyaningsih et al., 2010)

Uji organolaptik susu bubuk kedelai hitam dilakukan pada setiap hasil penambahan konsentrasi Tween 80, masing-masing 0,
$0,25, \quad 0,5,0,75$ dan 1 persen untuk mengetahui penerimaan konsumen pada masing-masing penambahan konsentrasi dengan jumlah panelis yang dianggap sebagai ulangan.

\section{Rancangan Percobaan}

Penelitian ini dilakukan dengan menggunakan Rancangan Acak Lengkap (RAL) monofaktor yang memiliki empat perlakuan dan satu kontrol. Variabel dependen penelitian ini adalah karakteristik fisik (daya serap air, kadar air dan laju pengendapan), sifat organolaptik (warna, rasa, aroma dan tekstur) dan aktivitas antioksidan, sedangkan variabel independennya yaitu penambahan konsentrasi Tween 80 dengan menggunakan kontrol susu bubuk kedelai hitam 100\% dan ditambahkan dekstrin 5\%. Setiap perlakuan dilakukan ulangan sebanyak 5 kali sehingga akan diperoleh percobaan sebanyak 5 x $5=25$ unit percobaan

\section{Analisis Data}


Data hasil pengukuran karakteristik fisik (daya serap air, kadar air, kelarutan dan laju pengendapan) dan aktivitas antioksidan yang diperoleh dikalkulasi dan dianalisa statistik menggunakan uji statistik ANOVA (Analysis of Varian), jika ada pengaruh dimana $\mathrm{p}$-value $<0,05$ maka dilakukan uji lanjut. Data hasil pengukuran sifat organoleptik ditabulasi dan dianalisa menggunakan uji Non Parametric
Friedman, jika ada pengaruh dimana $p$ value $<0,05$ maka diuji lanjut untuk mengetahui ada beda.

\section{HASIL DAN PEMBAHASAN}

\section{Daya Serap Air}

Hasil uji daya serap air susu bubuk kedelai hitam dengan variasi penambahan konsentrasi Tween 80 dapat dilihat pada Gambar 1.

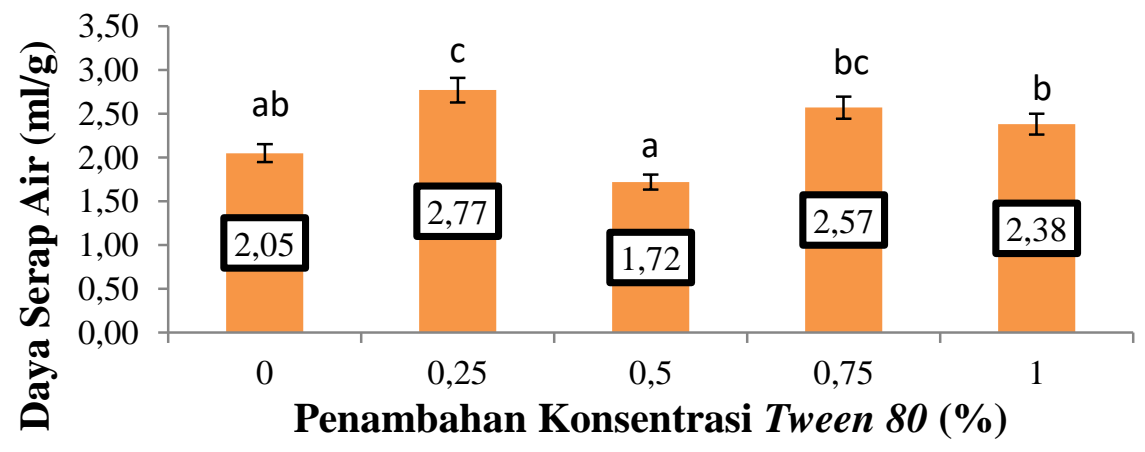

Gambar 1. Rerata Daya Serap Air Susu Bubuk Kedelai Hitam

Nilai rata-rata daya serap air pada susu bubuk kedelai hitam berkisar antara $1,72-2,77 \mathrm{ml} / \mathrm{g}$. Hasil analisis statistik menunjukkan penambahan konsentrasi Tween 80 berpengaruh nyata terhadap daya serap air susu bubuk kedelai hitam, hal ini ditunjukkan dengan nilai $\mathrm{P}$ sebesar 0,00 $(\mathrm{p}<0,05)$. Uji lanjut dengan menggunakan metode Duncan dengan taraf kepercayaan
95\% menunjukkan adanya perbedaan daya serap air susu bubuk kedelai hitam yang ditambahan berdasarkan konsentrasi Tween 80. Penambahan konsentrasi Tween 80 sebesar $0,25 \%$ menghasilkan nilai daya serap air yang tertinggi yaitu 2,77 ( $\mathrm{ml} / \mathrm{g})$, sedangkan perlakuan $0,5 \%$ menghasilkan nilai daya serap air terendah. Hasil tersebut lebih baik dibandingkan hasil penelitian 
yang dilakukan Purbasari (2016) yang menyatakan nilai daya serap air susu bubuk kedelai instan sebesar 1,46-1,68 ml/g.

Menurut Fennema (1996), gugus hidroksil mempunyai kemampuan mengikat air dari lingkungan dengan membentuk ikatan hidrogen. Menurut Winarno (1997), Tween 80 merupakan suatu bahan yang bersifat hidrofilik dan mempunyai daya tarik terhadap air serta mempunyai gugus hidroksil yang dapat membentuk ikatan hidrogen dengan molekul air sehingga memudahkan dalam penyerapan air.

\section{Kadar Air}

Kadar air dalam bahan pangan ikut menentukan kesegaran dan daya awet bahan pangan tersebut, kadar air yang tinggi mengakibatkan mudahnya bakteri, kapang, dan khamir untuk berkembang biak, sehingga terjadi perubahan pada bahan pangan (Winarno, 1997). Data pengamatan kadar air pada susu bubuk kedelai hitam dapat dilihat pada Gambar 2.

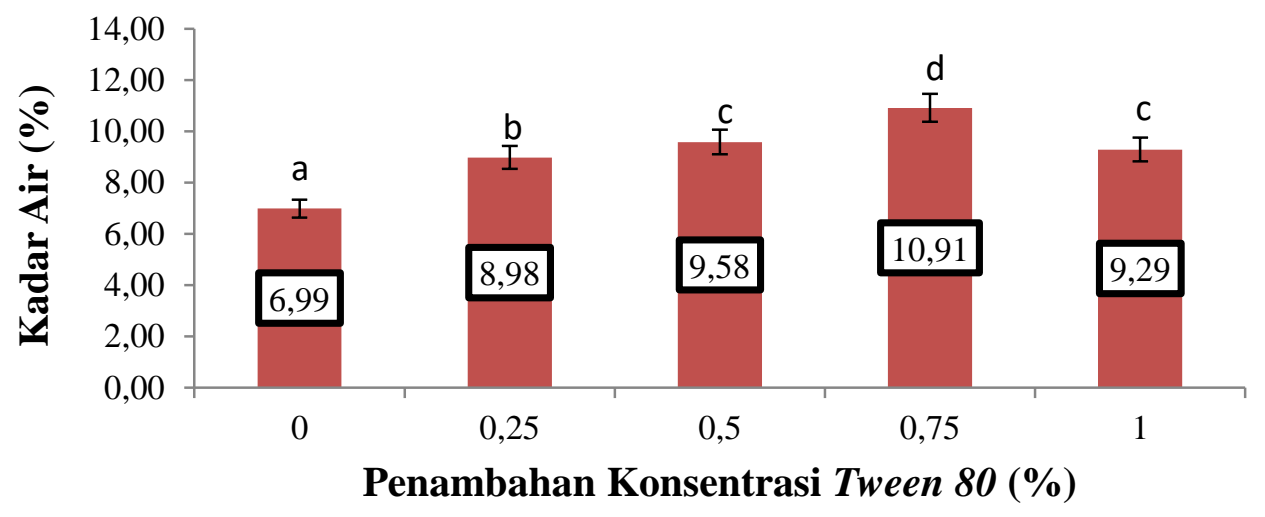

Gambar 2. Rerata Kadar Air Susu Bubuk Kedelai Hitam

Berdasarkan uji statistik penambahan konsentrasi Tween 80 berbeda menunjukkan bahwa penambahan pada masing-masing perlakuan kecuali konsentrasi Tween 80 berpengaruh nyata pada perlakuan $0,25 \%$ dan $1 \%$ tidak terhadap susu bubuk kedelai hitam dengan berbeda nyata. Penambahan konsentrasi nilai $\mathrm{P} 0,000(\mathrm{P}<0,005)$. Uji lanjut dengan Tween 80 sebesar $0,75 \%$ menghasilkan menggunakan metode Duncan dengan taraf nilai kadar air yang tertinggi yaitu 10,91\%, kepercayaan 95\% menunjukkan bahwa 
sedangkan perlakuan $0 \%$ menghasilkan nilai kadar air terendah dengan nilai 6,99\%. Peningkatan jumlah kadar ini disebabkan semakin tinggi penambahan Tween 80 akan meningkatkan jumlah buih pada saat pengeringan. Buih yang dihasilkan tidak dapat stabil dikarenakan penambahan dekstrin yang hanya $5 \%$ tidak dapat melapisi dan melindungi buih yang dihasilkan sehingga buih hilang pada saat pemanasan. Hal ini sependapat dengan pernyataan Tranggono et al., (1990) yang menyatakan penambahan konsentrasi Tween 80 yang melewati batas optimum penggunaannya akan mengakibatkan tingginya kadar air bahan hal ini dikarenakan pemakaian Tween 80 pada batas optimum akan bekerja sebagai pemecah buih. Buih yang tidak stabil selama proses pemanasan akan menghambat proses penguapan air bahan selama proses pengeringan sehingga ratarata kadar air bahan yang dihasilkan cukup tinggi (Tranggono et al., 1990)

\section{Kelarutan}

Data pengamatan kelarutan susu bubuk kedelai hitam dapat dilihat pada Gambar 3.

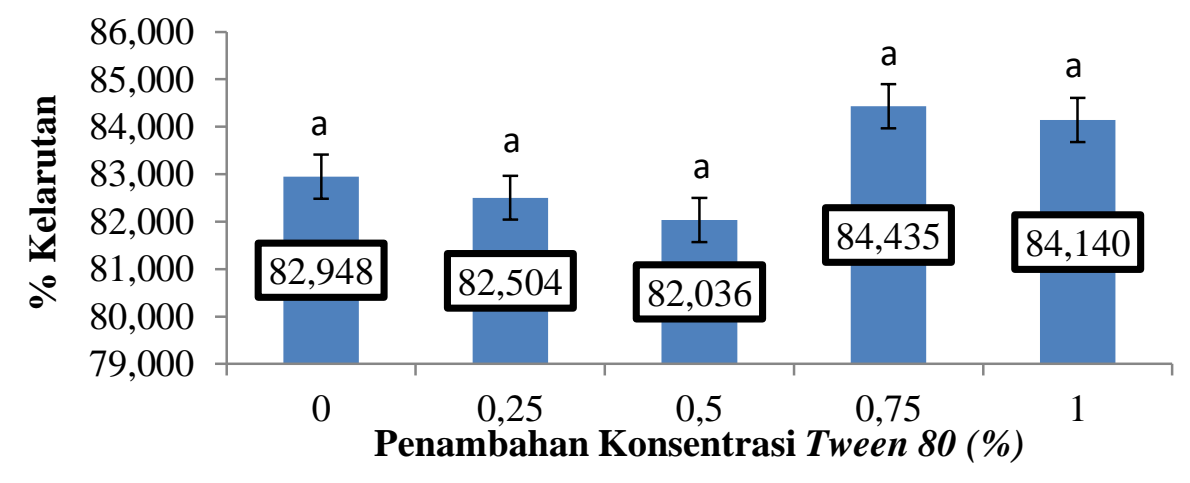

Gambar 3. Rerata Kelarutan Susu Bubuk Kedelai Hitam

Hasil analisis statistik menunjukkan

penambahan konsentrasi Tween 80 tidak berpengaruh terhadap kelarutan susu bubuk kedelai hitam, hal ini ditunjukkan dengan nilai P sebesar 0,068 ( $p>0,05)$. Nilai terbaik kelarutan diperoleh pada perlakuan $0,75 \%$ yaitu sebesar $84,435 \%$. Hasil tersebut lebih baik dibandingkan dengan penelitian yang 
dilakukan oleh Khotimah (2006) yang

menyatakan daya larut susu bubuk kedelai menggunakan metode foam-mat drying sebesar $52,70 \%-60,45 \%$.

Menurut Rowe et al., (2009) konsentrasi Tween 80 dapat mempercepat kelarutan suatu serbuk karena Tween 80 memiliki sifat larut dalam air sehingga akan meningkatkan kelarutan serbuk dalam air. Semakin tinggi penambahan Tween 80, porousitas bahan akan meningkat sehingga lebih mudah menyerap air dan lebih cepat larut dalam air. Kecepatan larut suatu bubuk berhubungan dengan ukuran granula bubuk tersebut. Granula susu bubuk yang kecil menyebabkan penyebaran granula kedalam air juga cepat. Dengan porousitas bahan yang besar dan ukuran granula yang cukup kecil meningkatkan kelarutan (Walstra 2003).

\section{Laju Pengendapan}

Data pengamatan laju pengendapan susu bubuk kedelai hitam dapat dilihat pada Gambar 4.

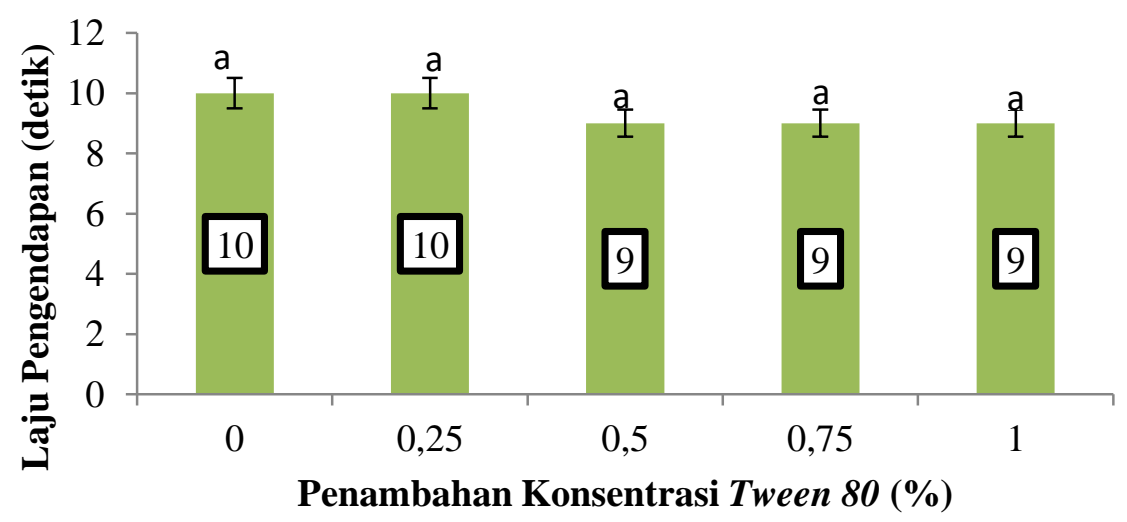

Gambar 4. Rerata Laju Pengendapan Susu Bubuk Kedelai Hitam

Hasil analisis statistik menunjukkan penambahan konsentrasi Tween 80 tidak berpengaruh terhadap laju pengendapan susu bubuk kedelai hitam, hal ini ditunjukkan dengan nilai $\mathrm{P}$ sebesar 0,192 ( $>>0,05)$. Nilai terbaik laju pengendapan diperoleh pada perlakuan $0,25 \%$ yaitu selama 10 detik namun hasil tersebut tidak berbeda nyata dengan semua perlakuan.

Tingginya laju pengendapan ini disebabkan oleh penggunaan medium air yang bersuhu $26^{\circ} \mathrm{C}$ pada saat melarutkan 
tersebut yang menyebabkan tingginya laju

pengendapan. Hal ini sependapat dengan

Gustantin (2015) butir-butir pati tidak dapat

larut dengan air dingin yang menyebabkan

semakin cepat laju pengendapan pada susu

kedelai. Dan apabila larutan pati encer

dibiarkan dengan beberapa lama maka akan

terbentuk endapan pada susu kedelai (

Gustantin, 2015).

\section{Warna}

Karakteristik warna pada susu bubuk kedelai pada umumnya adalah putih kekuningan. Hasil uji organoleptik terhadap warna susu bubuk kedelai hitam tersaji pada
Gambar 5. Gambar 5 menunjukkan bahwa semua perlakuan penambahan konsentrasi Tween 80 dapat diterima oleh panelis pada parameter dengan rata-rata $3,15-4,1$. Uji statistik menunjukkan perlakuan penambahan konsentrasi Tween 80 berpengaruh terhadap karakteristik warna susu bubuk kedelai hitam. Hal ini dibuktikan dengan nilai $\mathrm{P}$ 0,027 $(\mathrm{P}<0,05)$. Kemudian dilakukan uji lanjut Wilcoxon dengan taraf kepercayaan $95 \%$ menunjukkan bahwa penambahan Tween 80 berbeda nyata terhadap masing-masing perlakuan susu bubuk kedelai hitam.

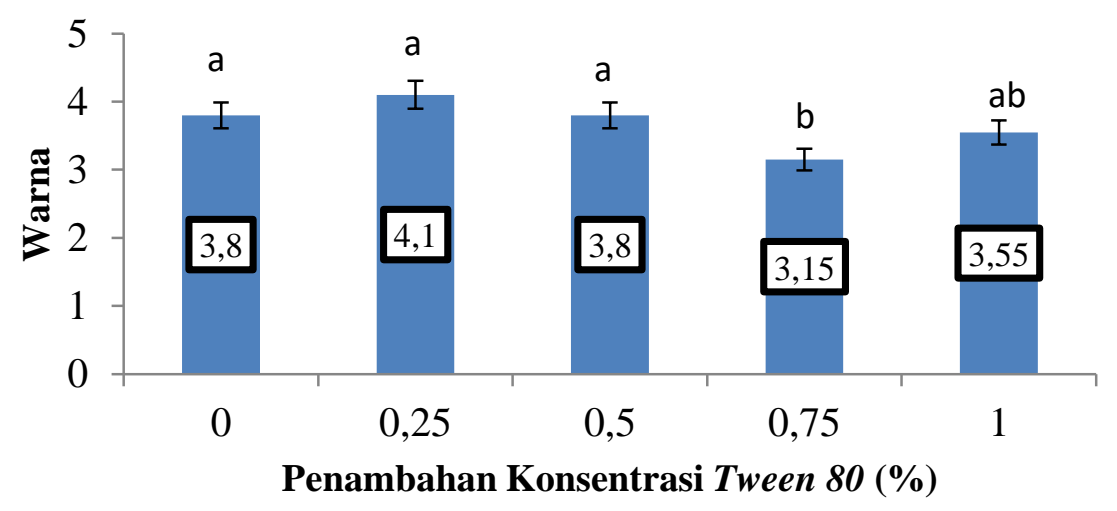

Gambar 5. Rerata Sifat Organoleptik Warna Susu Bubuk Kedelai Hitam

Perlakuan $0,25 \%$ merupakan susu bubuk kedelai hitam yang paling disukai pada parameter warna dengan nilai 4,1 dimana menghasilkan warna putih kekuningan. Namun pada perlakuan $0,25 \%$ tidak berbeda nyata dengan perlakuan $0,0,5$ dan 1 persen. Menurut Suryanto et al., (2001) penambahan konsentrasi dekstrin menyebabkan permukaan bahan semakin 
luas sehingga proses pengeringan lebih cepat dan tidak terjadi reaksi pencokelatan.

\section{Rasa}

Hasil analisis sifat organoleptik pada parameter rasa dapat dilihat pada Gambar 6. Gambar 6 menunjukkan bahwa sifat organoleptik pada parameter rasa dapat diterima oleh panelis dengan rata-rata 3,053,75 yaitu dengan nilai penerimaan agak suka dan nilai mutu hedonik agak manis. Semakin besar penambahan Tween 80 semakin menurunkan tingkat kesukaan panelis terhadap parameter rasa susu bubuk kedelai hitam.

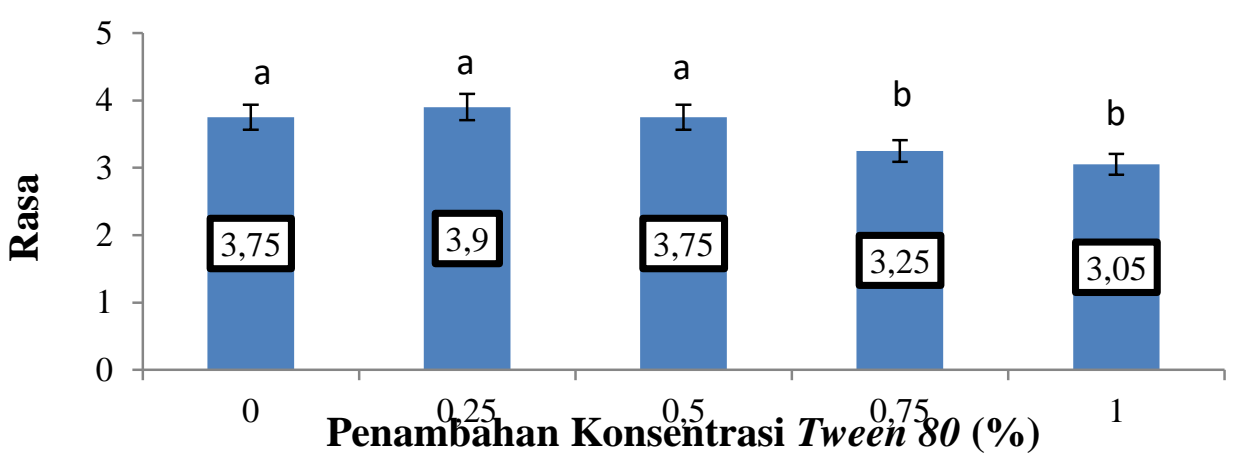

Gambar 6. Rerata Sifat Organoleptik Rasa Susu Bubuk Kedelai Hitam

Uji statistik menunjukkan bahwa

penambahan konsentrasi Tween 80

berpengaruh terhadap parameter rasa susu

bubuk kedelai hitam. Hal ini dibuktikan

dengan nilai $\mathrm{P}$ sebesar $0,003(\mathrm{P}<0,05)$. Uji

lanjut yang dilakukan menggunakan uji

Wilcoxon dengan taraf kepercayaan 95\%

menunjukkan bahwa penambaha

konsentrasi Tween 80 berbeda nyata

terhadap masing-masing perlakuan. Pada

penambahan konsentrasi $\quad 0,25 \%$

menunjukkan hasil yang paling disukai panelis pada parameter rasa, dengan nilai sebesar 3,9 (agak disukai) yang mendekati rasa suka dengan parameter mutu hedonik rasa agak manis.

\section{Aroma}

Pada umumnya susu bubuk kedelai hitam memiliki aroma yang khas yaitu langu yang ditimbulkan oleh kerja enzim lipoksigenase yang ada dalam biji kedelai. Data pengamatan sifatorganoleptik pada parameter aroma dapat dilihat pada Gambar 7. 


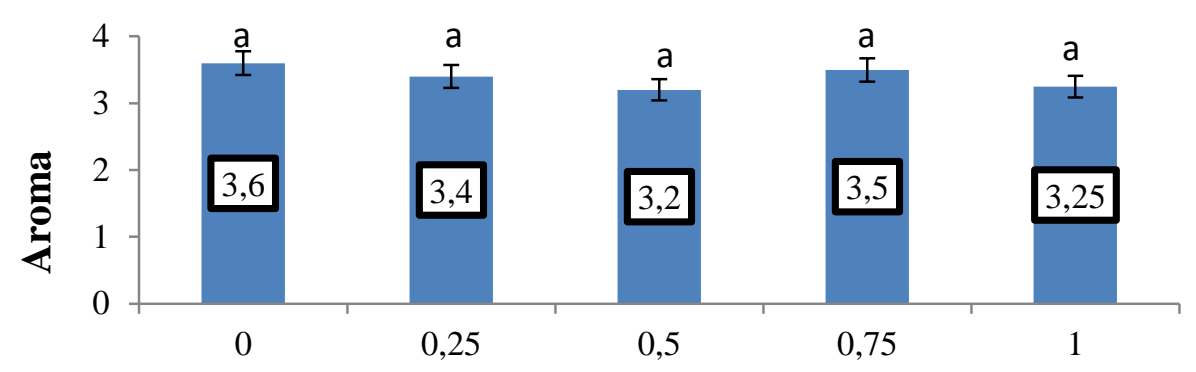

Penambahan Konsentrasi Tween 80 (\%)

Gambar 7. Rerata Sifat Organoleptik Aroma Susu Bubuk Kedelai Hitam

Gambar 7 dapat menunjukkan bahwa perlakuan penambahan Tween 80 dapat diterima oleh panelis dengan rata-rata 3,2 - 3,6 dengan hasil penilaian hedonik agak suka dan penilaian mutu hedonik dihasilkan aroma agak langu. Uji statistik yang dilakukan menunjukkan bahwa perlakuan penambahan Tween 80 tidak berpengaruh terhadap karakteristik aroma susu bubuk kedelai hitam. Hal ini dibuktikan dengan hasil nilai P 0,499 $(\mathrm{P}>0,05)$.

Menurut Hadiwiyoto (1999) Rasa dan aroma langu pada kedelai ditimbulkan oleh kerja enzim lipoksigenase yang ada dalam biji kedelai. Enzim tersebut akan bereaksi dengan lemak pada waktu penggilingan kedelai, terutama jika digunakan air dingin. Hasil reaksinya paling sedikit berupa delapan senyawa volatil (mudah menguap) terutama etilfenil-keton.

\section{Tekstur}

Data pengamatan tekstur susu bubuk kedelai hitam dapat dilihat pada Gambar 8.

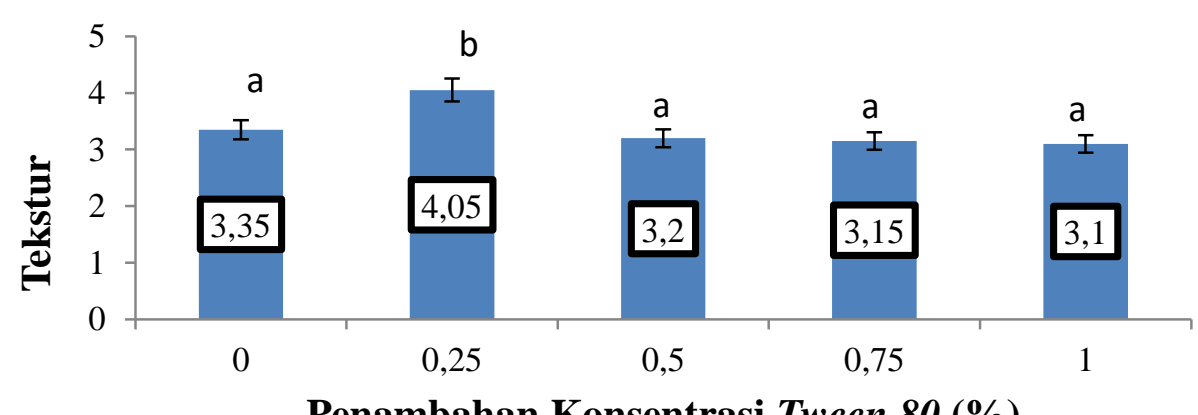


Gambar 8. Rerata Sifat Organoleptik Tekstur Susu Bubuk Kedelai Hitam

Uji statistik yang dilakukan bubuk kedelai hitam paling disukai panelis menunjukkan bahwa perlakuan dengan nilai sebesar 4,05 (suka) dengan penambahan Tween 80 berpengaruh parameter mutu hedonik halus. Sedangkan terhadap karakteristik tekstur susu bubuk perlakuan $1 \%$ paling tidak disukai panelis kedelai hitam. Hal ini dibuktikan dengan dengan nilai sebesar 3,1 (agak suka). hasil nilai $\mathrm{P} 0,023 \quad(\mathrm{P}<0,05)$. Uji lanjut Aktivitas Antioksidan dilakukan dengan menggunakan Wilcoxon Analisa aktivitas antioksidan dapat pada taraf kepercayaan $95 \%$ menunjukkan dilihat pada Gambar 9.

bahwa pada perlakuan $0,25 \%$ tekstur susu

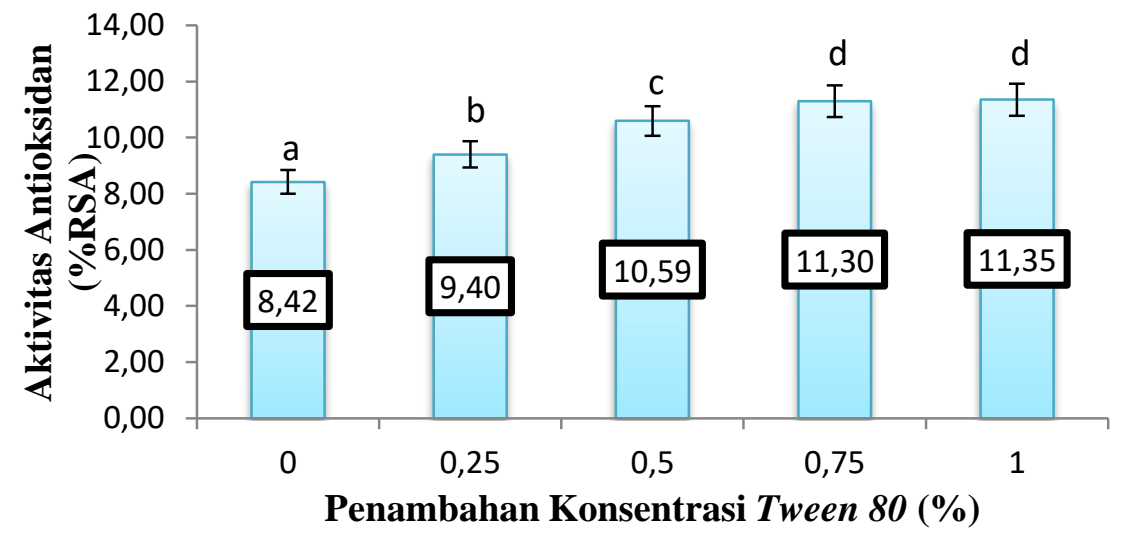

Gambar 9. Rerata Aktivitas Antioksidan Susu Bubuk Kedelai Hitam

Uji statistik menunjukkan P 0,000

$<0,00$ yang dapat disimpulkan bahwa

perlakuan penambahan konsentrasi Tween

80 berpengaruh terhadap aktivitas

antioksidan susu bubuk kedelai hitam. Uji

lanjut menggunakan metode Duncan

dengan taraf kepercayaan $95 \%$

menunjukkan adanya perberbedaan pada setiap perlakuan kecuali pada perlakuan $0,75 \%$ tidak berbeda nyata dengan perlakuan $1 \%$ pada penambahan konsentrasi Tween 80. Penambahan Tween 80 sebanyak $1 \%$ mempunyai aktivitas tertinggi dengan nilai $11,35 \%$ RSA dan perlakuan kontrol merupakan perlakuan terendah sebesar $8,42 \%$ RSA. 
Menurut Kumalaningsih et al., (2005) Tween 80 pada konsentrasi tertentu dapat berfungsi sebagai agen pembentukan busa. Pada konsentrasi 0,4-1 persen Tween 80 dapat membentuk busa. (Tranggono et al., 1990). Fungsi dari pembentukan busa dapat mempercepat proses pengeringan susu bubuk kedelai hitam, sehingga tidak merusak senyawa - senyawa penting seperti antioksidan dan senyawa lainnya.

\section{KESIMPULAN}

Berdasarkan penelitian yang telah dilakukan dapat disimpulkan bahwa penambahan konsentrasi Tween 80 berpengaruh nyata terhadap daya serap air, kadar air dan aktivitas antioksidan namun tidak berpengaruh teerhadap kelarutan dan laju pengendapan. Penambahan konsentrasi Tween 80 juga berpengaruh nyata terhadap sifat organoleptik warna, rasa dan tekstur namun tidak berpengaruh pada aroma susu bubuk kedelai hitam. Perlakuan terbaik diperoleh pada penambahan konsentrasi Tween 80 sebanyak $0,25 \%$.

\section{DAFTAR PUSTAKA}

Fennema dan Owen, R., 1996. Food Chemistry. Third Edition. Marcel Dekker, Inc., New York

Gustantin, A.S. 2015. Karakteristik fisik, kimia dan organoleptik susu berbahan baku kedelai (Glycine $\max ($ L.) Meriil) dan koro kratok (Phaseolus lunatus L.) putih dengan penambahan carboxy methyl cellulose. Fakultas Teknologi Pertanian Universitas Jember, Jember

Hadiwiyoto. 1999. Pengujian Mutu Susu Dan Hasil Olahannya : Liberty. Yogyakarta

Jiang S., Cai W., Xu B. 2013. Food quality improvement of soy milk made from short-time germinated soybeans. No. 2 : 198-212

Kumalaningsih, Suprayogi dan Beni, Y. M. A. 2005. Membuat MakananSiap Saji. TrubusAgrisarana, Surabaya

Lees, R. 1971. Laboratory Handbook of Methods of Analysis. Leonard Hill. London, UK

Noer, L., Epy, M.L., Bambang, S.L. 2009. The effect of black soybean milk on lover to recovery hispathology in rat with high fat diet. Fakultas Kedokteran Hewan Universitas Airlangga, Surabaya

Pertiwi, S.F., Aminah, S., Nurhidajah. 2013. Aktivitas antioksidan, karakteristik kimia dan sifat organolaptik susu kecambah kedelai hitam (Glycine soja) berdasarkan variasi waktu perkecambahan. (Skripsi). Program Studi S1 Teknologi Pangan Universitas Muhammadiyah Semarang, Semarang

Purbasari, D. 2016. Aplikasi metode foammat drying dalam pembuatan bubuk susu kedelai instan. 
Fakultas Teknologi Pertanian Universitas Jember, Jember

Rowe, R.C., Sheskey, P.J. dan Quinn M., E. 2009. Handbook of pharmaceutical excipients. LexiComp: American Pharmaceutical Assosiation, Inc.

Sari, N.P., Ikrawan Y.M., Hervelly. 2016. Pengaruh konsentrasi putih telur dan tween 80 terhadap karakteristik minuman cokelat instan. Universitas Teknik Universitas Pasundan, Bandung

Setyaningsih, D. A., Apriyantono, A dan, Sari M. P. 2010. Analisis sensori untuk industri pangan dan agro. IPB Press, Bogor

Sudarmadji, S. Haryono, B., dan Suhardi. 1984. Prosedur Analisa untuk Bahan Makanan dan Pertanian. Liberty, Yogyakarta.

Suryanto, R.. S. Kumalaningsih dan T. Susanto. 2001. Pembuatan bubuk sari buah sirsak (Annona muricata L.) dari bahan baku pasta dengan metode foam-mat drying. $\mathrm{J}$. Biosains, 1 (1): 47-60.

Tamrin. 2012. Perubahan aktivitas antioksidan kakao pada pengeringan vakum. Fakultas Pertanian. Universitas Haluoleo, Kendari

Traina, M.S. dan Breene W.M. 1994. Composition, functionality and some chemical and physical properties of eight commercial full-fat soy flour. Food Process 8 : 229-252

Tranggono dan Haryadi. 1990. Bahan Tambahan Pangan (Food Additives). Pusat Antar Universitas Pangan dan Gizi. UGM, Yogyakarta.
Walstra, P. 2003. Physical Chemistry of Foods. Marcel Dekker. Inc. New York

Winarno, F.G. 1997. Kimia Pangan dan Gizi. PT Gramedia Pustaka Utama : 4-11, Jakarta 